\title{
Effects of biological disturbance by benthic amphipods Monoporeia affinis on meiobenthic community structure: a laboratory approach
}

\author{
Emil 'Olafsson, Ragnar Elmgren \\ Department of Zoology and Askö Laboratory, Department of Systems Ecology, Stockholm University, S-106 91 Stockholm, \\ Sweden
}

\begin{abstract}
In order to evaluate the importance of biological disturbance on meiofaunal communities in muddy habitats, a laboratory experiment was performed at the Askö Laboratory in the northwestern Baltic proper The benthic amphipod Monoporeia affinis (Lindström) was added to microcosms containing sublittoral mud, in quantities varying from zero up to 80 ind $104 \mathrm{~cm}^{-2}$ After 2 mo the density of nematodes, the most abundant meiofauna taxon $(97 \%)$, was greatest in microcosms without amphipods, but they also occurred in higher numbers in microcosms containing a high density of $M$. affinis, compared to low and medium density microcosms. $M$. affinis appears to have a negative effect on surface-dwelling nematode species but a positive effect on the deeper dwelling Daptonema sp. However, nematode assemblage structure remained very similar in all treatments. Copepod abundances increased with increasing numbers of amphipods $(\mathrm{p}<0.002)$ and were highest in the high density microcosms. In the microcosms without amphipods, Macoma balthica spat was almost twice as abundant as in the amphipod treatments. For kinorhynchs and turbellarians there were also significant differences between treatments. The different responses of the major taxa to the biological disturbance may reflect the multifactorial nature of biotic perturbations.
\end{abstract}

\section{INTRODUCTION}

Abundance, composition and number of species in a given habitat is determined by an array of abiotic and biotic factors. The frequency and magnitude of disturbance have been found to be important organizing factors for assemblages of marine benthic organisms (Paine 1966, Dayton 1971, Connell 1978). How researchers define and quantify the term disturbance is not always clear. This is especially true of biological disturbance which can encompass selective and nonselective predation as well as a variety of habitat modifications resulting from feeding and bioturbation by the disturber.

The activities of the macrofauna are a source of disturbance which may influence the structure of meiofaunal assemblages (Reise \& Ax 1979, Thistle 1980, Reidenauer \& Thistle 1981, Sherman et al. 1983, Creed \& Coull 1984, Hicks 1984, Warwick et al. 1986, Palmer 1988, Warwick et al. 1990, 'Olafsson \& Moore 1990, 'Olafsson et al. 1990, Sundelin \& Elmgren 1991). However, there are few reports on experiments where the intensity of biological disturbance has been graded into more than 2 categories, i.e. disturbance or no disturbance, a refinement which may prove necessary to understanding the mechanism behind the perturbation.

The use of meiobenthos in studying changes at the community level in manipulative controlled meso- or microcosm experiments has many advantages. For the rationale behind this approach see for example Warwick et al. (1988). It may be briefly stated here that due to the life history characteristics, small size, short turnover time and direct benthic development of meiobenthic animals, community responses can be measured on realistic spatial and temporal scales in such experiments, while this is usually not the case for macrofauna.

In most of the Baltic Sea the bivalve Macoma balthica (L.) and the amphipod Monoporeia affinis (Lindström) (syn. Pontoporeia affinis; of. Bousfield 1989) are the dominant macrobenthic species (Elmgren et al. 1986). $M$. affinis, in particular, is very abundant and is found in the muddy substrata in densities ranging up to several thousand per $\mathrm{m}^{2}$. In the Askö-Landsort area (Sweden) M. affinis was the most abundant macrofaunal species, constituting $46 \%$ of all macrobenthic 
animals and averaging 1643 ind. $\mathrm{m}^{-2}$ (Ankar \& Elmgren 1976). $M$. affinis is a deposit feeder, found mainly in the top $5 \mathrm{~cm}$ of the sediment (Hill \& Elmgren 1987) but feeds primarily in the surface layer (Lopez \& Elmgren 1989). Its diet seems to consist mainly of detrital matter (pers. obs.), but nematodes have been found among the gut contents of some Pontoporeia specimens (Elmgren 1976) and it can consume newly settled bivalve spat (Elmgren et al. 1986). Monoporeia spp. are also active bioturbators able to rework the sediment and for example enhance redox levels in deeper layers (Robbins 1982, Elmgren et al. 1986). In a long-term (>1 yr) laboratory experiment, Sundelin \& Elmgren (1991) found that $M$. affinis affected the densities of some of the major meiofaunal taxa.

The activities of Monoporeia affinis are likely to affect the meiobenthos in various ways. As many nematode and copepod species are detritus feeders (see for review Hicks \& Coull. 1983. Heip et al, 1985) the availability of basic nutrients may decrease with increasing density of the amphipods and hence reduce growth rates of competitors. This combined with direct predation (which can prevent competitive equilibrium between meiofaunal species) may result in reduced population size and enhanced species diversity according to Huston's (1979) general hypothesis. The reworking of the sediment is also likely to favour some species while reducing the abundance of others and hence influence the structure of the meiofaunal assemblage.

\section{MATERIALS AND METHODS}

Experimental setup. Small aquaria were established at the Askö Laboratory field station in the northwestern Baltic proper $\left(58^{\circ} 49^{\prime} \mathrm{N}, 17^{\circ} 38^{\prime} \mathrm{E}\right)$ in July 1989. Each microcosm consisted of a 2 l glass jar with a total surface area of about $104 \mathrm{~cm}^{2}$, as described by Elmgren et al. (1986). Brackish water was pumped from a depth of $16 \mathrm{~m}$ into a cooling tank and distributed to the microcosms through dripping needles. Outflow water from the microcosms was not recycled. Temperature and salinity were kept near field levels i.e. 5 to $7^{\circ} \mathrm{C}$ and 6.6 to $7.2 \%$, and a dim green light, controlled by an outdoor photocell, simulated in situ light conditions.

Sediment dominated by Monoporeia affinis was collected using a benthic dredge from a $34 \mathrm{~m}$ deep station, ca $3 \mathrm{~km}$ south of the Askö Laboratory. Kajak cores (Blomqvist \& Abrahamsson 1985) were also obtained and the top layer of each core used to enrich the meiofauna in the microcosms. The sediment was sieved through a $0.5 \mathrm{~mm}$ mesh to exclude macrofauna, allowed to settle, homogenized by stirring and added to the glass jars.

A total of 45 microcosms were used, to permit 5 treatments levels of 9 replicates each, arranged in a randomized block design.

At the start of the experiment, $3 \mathrm{wk}$ after sediment collection, 9 microcosms were removed to serve as initial controls. A further 9 were maintained without amphipods, while the remainder were set up with 3 amphipod treatment levels: 20,40 and 80 individuals per microcosm, corresponding to low, medium and high field densities.

The amphipods were collected from the same location as the sediment, just prior to the start of the experiment. In the low density treatments only subadult $(1+y r)$ specimens were used. In the higher density treatments some (around $14 \%$ ) larger juveniles $(0+$ group) were employed.

The experiment was terminated after $2 \mathrm{mo}$, and the contents of each microcosm fixed in $4 \%$ buffered formalin. The samples were sieved through $500 \mu \mathrm{m}$ and 40 $\mu \mathrm{m}$ mesh sieves and the $40 \mu \mathrm{m}$ screenings were transferred to 2 l conical flasks and suspended in Ludox (colloidal silica polymer) at a specific gravity of 1.15 . After settling overnight the supernatant liquid was decanted through a $40 \mu \mathrm{m}$ mesh. The sediment was then resuspended in Ludox and the process repeated once more. The residue in the conical flask was examined for 5 samples. The average extraction efficiency for nematodes, copepods and other groups combined was $98 \%$ (range 97 to $99 \%$ ), $87 \%$ (range 70 to $100 \%$ ) and $71 \%$ (range 58 to $84 \%$ ) respectively. The extracted meiofauna sample was resuspended in $50 \mathrm{ml}$ of tap water and vigorously agitated. Subsamples were then taken with a syringe, $50 \mathrm{ml}$ for the nematodes and 250 for other taxa. Meiofauna was enumerated and identified to major taxa in a petri dish under a stereo dissecting microscope. Foraminifera were excluded from the study as they were not reliably extracted with the floatation method used. From each of the $50 \mathrm{ml}$ subsamples about 100 nematodes were picked out randomly, impregnated with anhydrous glycerine (Platt \& Warwick 1983) and mounted on slides for identification under a high-power microscope. Given the small differences in the abundance of the major meiofaunal taxa between low and medium amphipod treatments, nematodes were not determined to species in the low treatment, in order to save time.

For comparison, a Kajak core sample from the sediment collection site, taken on 14 October 1988 was sectioned into 4 layers: $0-1,1-2,2-4$ and $4-6 \mathrm{~cm}$. One hundred nematodes from each layer were identified as above.

For each taxon, differences in density between the treatments were investigated by means of 1 -way analysis of variance. Paired a posteriori comparisons of density estimates were carried out with the Tukey test using $95 \%$ confidence limits. Prior to the analysis of 
variance, all data were first $\log _{10}(x+1)$ transformed and Bartlett's test used to check the assumption of homoscedasticity. When conditions for the use of parametric tests were not fulfilled, Kruskal-Wallis tests and Spearman's rank correlation were employed.

Nematode species abundance data were double square root transformed, and subjected to detrended correspondence analysis using DECORANA adapted for microcomputers (Hill 1979). A computer program by Moore (1983) was used to calculate various species diversity indices. $K$-dominance curves were plotted for the combined replicates of each treatment, using the method of Lambshead et al. (1983), and significance testing was carried out according to Clarke (1990) using the ANOSIM randomization test.

\section{RESULTS}

\section{Microcosm experiment}

The survival rate of the amphipods inside the microcosms was high (on average $90 \%$ ) and very similar between treatments (Table 1). The number of dead amphipods was highest in the high density treatment.

The initial densities of the major taxa, when the amphipods were introduced to the microcosms, are shown in Table 2. The initial major taxa composition reflects the findings in the field, exhibiting a very high predominance of nematodes. Compared to the field densities all taxa had lower abundances inside the microcosms, nematode and copepod numbers being only about $1 / 2$ and $1 / 10$ respectively of the field values. The coefficient of variation among microcosms differed between the major taxa. Copepods and nematodes showed the least variation, the coefficient being $18 \%$ and $13 \%$ respectively, while other taxa varied more (Table 2).

\section{Major taxa}

Comparison between the initial microcosms and microcosms without amphipods after 2 mo revealed that all the major meiofaunal taxa were in similar numbers (Mann-Whitney $U$ tests, $\mathrm{p}>0.05$ ), apart from copepods which had increased with time (Mann-Whitney $U$ test, $\mathrm{p}<0.05$ ).

Average numbers of the major meiofaunal taxa in each treatment are represented in Table 1 along with the results of statistical tests. There was a significant difference in the number of nematodes among experimental treatments. They were most abundant within microcosms without amphipods. Nematodes were also significantly more abundant in microcosms containing

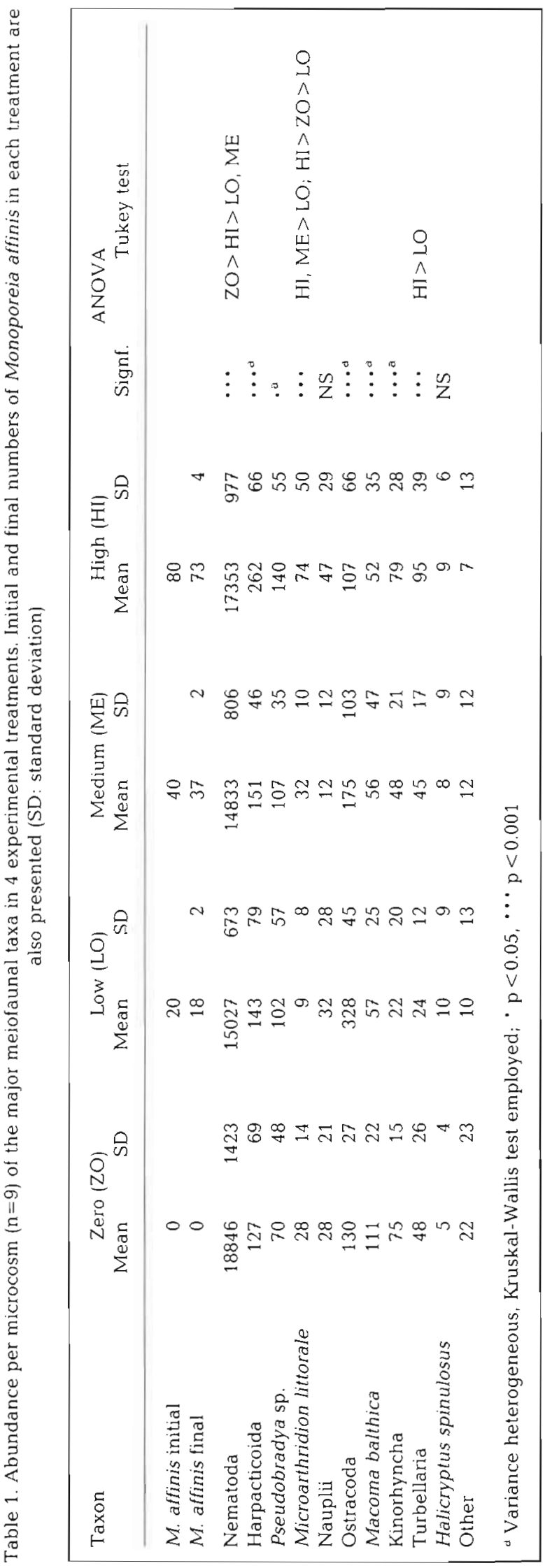


Table 2. Abundance per microcosm ( $n=9)$ of major meiofaunal taxa at the start of the experiment

\begin{tabular}{|c|c|c|c|c|}
\hline Taxon & Mean & $\begin{array}{l}\text { Standard } \\
\text { deviation }\end{array}$ & Percentage & $\begin{array}{c}\text { Coefficient of } \\
\text { variation }\end{array}$ \\
\hline Nematoda & 17190 & 2214 & 97.5 & 13 \\
\hline Harpacticoida & 64 & 12 & 0.3 & 18 \\
\hline Pseudobradya sp. & 33 & 8 & 0.2 & 23 \\
\hline Microarthridion littorale & 29 & 10 & 0.2 & 36 \\
\hline Nauplii & 2 & 2 & 0.01 & 88 \\
\hline Ostracoda & 119 & 75 & 0.7 & 63 \\
\hline Macoma balthica & 82 & 19 & 0.5 & 23 \\
\hline Kinorhyncha & 57 & 23 & 0.3 & 41 \\
\hline Turbellaria & 34 & 31 & 0.2 & 91 \\
\hline Halicryptus spinulosus & 9 & 6 & 0.05 & 71 \\
\hline Other & 9 & 8 & 0.05 & 87 \\
\hline
\end{tabular}

high densities of Monoporeia affinis when compared with low and medium density microcosms.

For the copepods as a group there was also a significant difference among experimental treatments (Table 1). Copepod abundances were highest in the high density microcosms, and increased on average with increasing numbers of amphipods (Spearman rank correlation, $\mathrm{r}_{\mathrm{s}}$ $=0.5629, \mathrm{n}=33, \mathrm{p}=0.0015)$. This was reflected in the numbers of the 2 copepod species found, Pseudobradya sp. and Microarthridion littorale (Poppe). Nauplii were most abundant in the high density microcosms, but the difference was not significant.

A significant difference was found in the numbers of ostracods (Table 1). They were on average about twice as abundant in the low density microcosms as in the other treatments. In the microcosms without Monoporeia affinis, Macoma balthica was almost twice as abundant as in the other treatments (Table 1). Numbers of kinorhynchs varied significantly among treatments. Like the nematodes, numbers were highest in the zero and high density microcosms. Turbellarians were most abundant in high density microcosms but values only differed significantly from those of the low density microcosms (Table 1).

\section{Nematode assemblage structure}

Altogether 25 nematode species were found in the microcosms. Sabatieria pulchra G. Schneider was the dominant species in all microcosms, comprising about one third of the average density in all treatments (Table 3). Other important species were Leptolaimus elegans (Schuurmans Stekhoven \& De Coninck), Daptonema sp. 1, and Calomicrolaimus honestus De Man. These constituted on average $21 \%, 10 \%$ and $8 \%$ respectively of the total numbers (Table 3). Of the 10 most abundant species, there was a significant difference between treatments for 2 species. Daptonema sp. 1 was found in higher numbers in the high density treatment compared to medium density (ANOVA, Tukey test, $p<0.05$ ) and $C$. honestus showed a significant difference between treatments (Kruskal-Wallis, p <0.05), with highest abundance in the zero treatment.

Detrended correspondence analyses failed to show any groupings of treatments (Fig. 1) and only a small proportion of the variance was attributable to the first axis (eigenvalue $=0.12$ )

Some of the univariate measurements showed significant differences between treatments (Table 4), e.g.

Table 3. Mean ( $n=8$ ) numbers of the 9 most abundant nematode species in the initial control jars, zero, medium and high treatments (nematode species determination not performed for samples from the low treatment)

\begin{tabular}{|lrrrrrrrrrrrr}
\hline \multirow{2}{*}{ Species } & \multicolumn{3}{c}{ Initial control } & \multicolumn{3}{c}{ Zero } & \multicolumn{3}{c}{ Medium } & \multicolumn{2}{c}{ High } \\
& Mean & \multicolumn{1}{c}{ SD } & $\%$ & Mean & SD & $\%$ & Mean & SD & $\%$ & Mean & SD & \% \\
\hline Sabatieria pulchra & 4787 & 1039 & 28 & 5529 & 891 & 30 & 5735 & 972 & 39 & 5495 & 1294 & 32 \\
Leptolaimus elegans & 3673 & 936 & 22 & 3915 & 1004 & 21 & 3148 & 1221 & 21 & 3433 & 823 & 20 \\
Daptonema sp. 1 & 1781 & 1094 & 10 & 1713 & 441 & 9 & 1082 & 466 & 7 & 2188 & 799 & 13 \\
Calomicrolaimus honestus & 1325 & 754 & 8 & 1739 & 537 & 9 & 845 & 410 & 6 & 1413 & 626 & 8 \\
Eleutherolaimus sp. 1 & 700 & 443 & 4 & 1131 & 370 & 6 & 815 & 394 & 6 & 1159 & 479 & 7 \\
Desmolaimus sp. 1 & 834 & 454 & 5 & 956 & 334 & 5 & 1113 & 665 & 8 & 782 & 371 & 5 \\
Leptolaimus papilliger & 973 & 574 & 6 & 1055 & 509 & 6 & 473 & 379 & 3 & 959 & 584 & 6 \\
Paracanthonchus caecus & 598 & 441 & 4 & 913 & 415 & 5 & 356 & 248 & 2 & 272 & 220 & 2 \\
Chromadorita fennica & 636 & 416 & 4 & 671 & 340 & 4 & 315 & 294 & 2 & 336 & 229 & 2 \\
\hline
\end{tabular}


lower diversity, as expressed by $H^{\prime}, D$ and $J^{\prime}$, in the medium density microcosms compared to the initial and zero density microcosms. The $K$-dominance plot (Fig. 2) for combined samples from individual treatments indicates highest rank one dominance in the medium density microcosms compared to other treatments. Paired comparisons of the K-dominance curves, using ANOSIM significance testing, showed that there was a significant difference between medium density treatment and both initial control and zero density treatments $(\mathrm{p}<0,01)$.

\section{Natural meiofauna}

Table 5 shows the composition and the depth distribution of the major meiofaunal taxa and the 10 most abundant nematode species, as determined from the Kajak core sample. As expected, nematodes were the dominant group, comprising more than $90 \%$ of the total meiofauna. They were most abundant in the upper layers, though found in considerable numbers between 2 and $4 \mathrm{~cm}$. Other taxa seem to be confined to the top $1 \mathrm{~cm}$ of the sediment, apart from turbellarians and kinorhynchs.

Of the 18 nematode species recorded, Calomicrolaimus honestus and Paracanthonchus spp. (mainly $P$. caecus Bastian) dominated the surface layer (Table 5). There was a shift in the composition in the $1-2 \mathrm{~cm}$ layer, where Leptolaimus elegans and L. papilliger De Man dominated along with Microlaimus globiceps De Man. Two species, Sabatieria pulchra and Daptonema sp. 1 , were found in considerable numbers in the $2-4$ $\mathrm{cm}$ layer. $K$-dominance plots of the nematode species from each depth zone indicated that the fauna from the 1-2 cm layer was the most diverse and that dominance was highest in the top layer. This was consistent with diversity indices which were highest for the

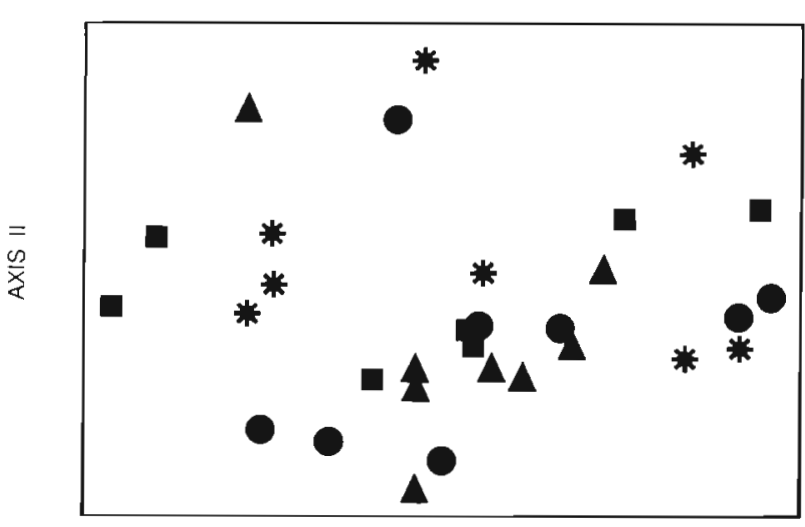

AXIS I

Fig. 1. Two-dimensional configuration (detrended correspondence analysis) of samples of nematode species from 3 treatments and initial control. (*) Initial control; ( $\mathbf{\Delta}$ ) 0 Monoporeia affinis; (ロ) $40 \mathrm{M}$. affinis; ( $80 \mathrm{M}$. affinis

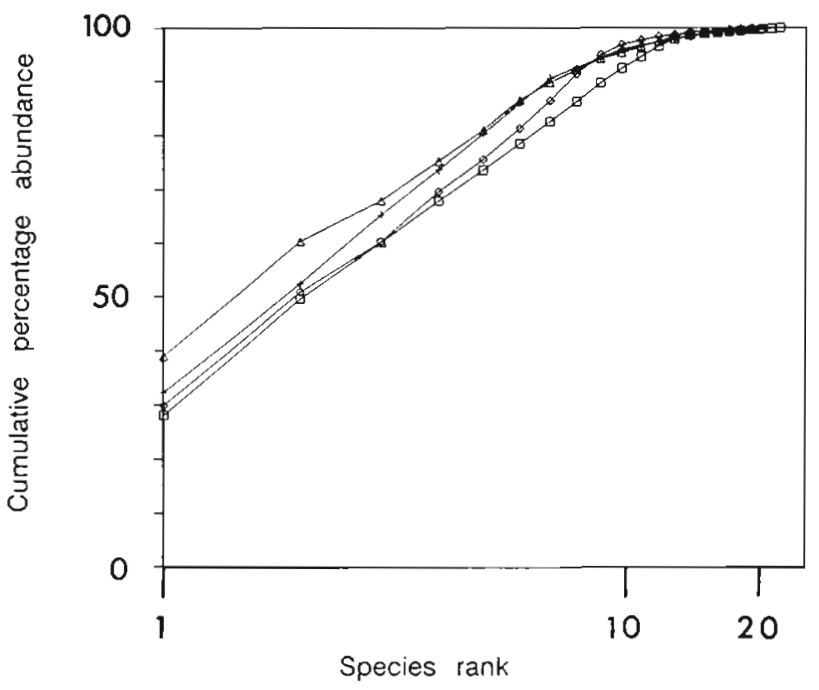

Fig. 2. $K$-dominance curves derived from combined replicates for 3 treatments and initial control for all nematode species. $(\square)$ Initial control; $(0) 0$ Monoporeia affinis; $(\Delta) 40 \mathrm{M}$ affinis; (+) $80 \mathrm{M}$. affinis

Table 4. Mean $(\mathrm{n}=8)$ values of nematode species diversity indices $\left(H^{\prime} \cdot\right.$ Shannon-Wiener; $D$ : Simpson), evenness $\left(f^{\prime}\right.$. Pielou) and richness ( $S$ : Sanders rarefaction at the 50 individual level) in 4 experimental treatments and from the fjeld. Significance levels presented are $p<0.05, \cdots p<0.01, \cdots p<0.001$ and there is no significant difference (Tukey test) between treatments where the + sign is in the same vertical position

\begin{tabular}{|c|c|c|c|c|c|}
\hline Treatment & \multicolumn{2}{|c|}{$H^{\prime}$} & $D$ & $J^{\prime}$ & $S$ \\
\hline Initial control (IC) & \multicolumn{2}{|c|}{3.00} & 0.84 & 0.82 & 10.91 \\
\hline No amphipods ( $\mathrm{ZO})$ & \multicolumn{2}{|c|}{2.94} & 0.84 & 0.83 & 10.38 \\
\hline Medium amphipod density (ME) & \multicolumn{2}{|c|}{2.66} & 0.78 & 0.75 & 9.87 \\
\hline High amphipod density $(\mathrm{HI})$ & \multicolumn{2}{|c|}{2.82} & 0.82 & 0.80 & 9.99 \\
\hline ANOVA (Significance level) & \multicolumn{2}{|c|}{$\cdot$} & $\cdots$ & • & NS \\
\hline \multirow[t]{4}{*}{ Tukey test } & ME & & + & + & \\
\hline & $\mathrm{HI}$ & + & ++ & ++ & \\
\hline & $\mathrm{ZO}$ & + & + & + & \\
\hline & & + & + & + & \\
\hline Field data & \multicolumn{2}{|c|}{3.40} & 0.88 & 0.82 & 12.03 \\
\hline
\end{tabular}


Table 5. Vertical distribution (no. per $10 \mathrm{~cm}^{2}$ ) of the major meiofaunal groups and the 10 most abundant nematode species from the field station on 14 October 1988

\begin{tabular}{|c|c|c|c|c|c|c|}
\hline \multirow[t]{2}{*}{ Taxon } & \multicolumn{4}{|c|}{ Depth interval } & \multirow[t]{2}{*}{ Total } & \multirow[t]{2}{*}{ Percentage } \\
\hline & $0-1 \mathrm{~cm}$ & $1-2 \mathrm{~cm}$ & $2-4 \mathrm{~cm}$ & $4-6 \mathrm{~cm}$ & & \\
\hline Nematoda & 1544 & 2294 & 707 & 127 & 4671 & 92 \\
\hline Leptolaimus papilliger & 131 & 573 & 127 & 32 & 864 & $19^{\mathrm{d}}$ \\
\hline Calomicrolaimus honestus & 657 & 46 & 21 & 9 & 733 & $16^{\mathrm{at}}$ \\
\hline Leptolaimus elegans & 82 & 436 & 170 & 18 & 705 & $15^{\mathrm{a}}$ \\
\hline Paracanthonchus spp. & 345 & 184 & 21 & 3 & 552 & $12^{\mathrm{a}}$ \\
\hline Microlaimus globiceps & 33 & 413 & 14 & 1 & 461 & $10^{\mathrm{a}}$ \\
\hline Sabatieria pulchra & 0 & 92 & 205 & 45 & 341 & $7^{a}$ \\
\hline Daptonema sp. 1 & 0 & 92 & 106 & 3 & 200 & $4^{2}$ \\
\hline Ascolaimus sp. 1 & 131 & 0 & 0 & 0 & 131 & $4^{a}$ \\
\hline Axonolaimus sp. 1 & 49 & 69 & 0 & 1 & 119 & $3^{a}$ \\
\hline Chromadorita fennica & 66 & 0 & 28 & 4 & 98 & $3^{a}$ \\
\hline Harpacticoida & 244 & 2 & 2 & 0 & 248 & 4.9 \\
\hline (adults \& copepodites) & 153 & 0 & 2 & 0 & 155 & 3.1 \\
\hline (nauplii) & 91 & 2 & 0 & 0 & 93 & 1.8 \\
\hline Kinorhyncha & 42 & 25 & 0 & 2 & 69 & 1.4 \\
\hline Ostracoda & 29 & 2 & 0 & 0 & 30 & 0.6 \\
\hline Macoma balthica & 13 & 2 & 0 & 1 & 15 & 0.3 \\
\hline Turbellaria & 2 & 9 & 2 & 0 & 13 & 0.3 \\
\hline Rotifera & 13 & 0 & 0 & 0 & 13 & 0.3 \\
\hline Hydrozoa & 4 & 0 & 0 & 0 & 4 & 0.1 \\
\hline Polychaeta & 2 & 0 & 0 & 0 & 2 & $<0.1$ \\
\hline Halicryptus spinulosus & 2 & 0 & 0 & 0 & 2 & $<0.1$ \\
\hline Halacarida & 1 & 0 & 0 & 0 & 1 & $<0.1$ \\
\hline Unidentified & 0 & 1 & 0 & 0 & 1 & $<0.1$ \\
\hline Total & 1896 & 2334 & 710 & 130 & 5070 & \\
\hline
\end{tabular}

1-2 cm layer for all measurements but lower and very similar in all other layers.

\section{DISCUSSION}

The impact of the amphipods on the meiofauna in the microcosms was taxon specific. The higher abundance of nematodes in microcosms without amphipods might be due to predation, competition or physical factors. Sundelin \& Elmgren (1991) also found higher numbers of nematodes in microcosms without amphipods in similar experiment of longer duration (265 d). Even though there was no clear cut pattern in the structure of the nematode assemblage between treatments, the elevated numbers in the microcosms without amphipods were due to higher numbers of the surface dwellers, e.g. Leptolaimus elegans, Calomicrolaimus honestus, L. papilliger and Paracanthonchus caecus, though this difference was only significant in the case of $C$. honestus. If predation played an important role inside the microcosms one would expect nematode numbers to decline with increasing amphipod density. This expectation was not born out by the results, where we instead found only small differences in the density of the most abundant nematode species between treatments.

In intertidal areas subjected to predation/disturbance a reduction in the density of nematodes in the surface layers (within the top $5 \mathrm{~mm}$ ) has been reported (Reise 1979, Fitzhugh \& Fleeger 1985). Indeed Fitzhugh \& Fleeger (1985) found that nematode abundance increased in deeper layers, perhaps as a result of downward migration due to sediment disturbance. In the current study it is conceivable that when amphipods were present surface dwelling nematodes migrated deeper into the sediment resulting in lower survival or reproduction due to other limiting factors

Nematodes were found in higher numbers in the high density microcosms compared to the low and medium density microcosms. This was mainly due to increased numbers of the relatively deep dwelling Daptonema sp. 1, possibly due to enhanced food resources or favourable chemical conditions resulting from the bioturbating activities of the amphipods. The input of organic matter from dead amphipods may also have enhanced food resources in the high density microcosms (cf. Table 2).

Despite differences in the abundance of a few species, the nematode assemblage structure remained 
very similar between treatments. This finding was quite unexpected and can be explained in one of 2 ways. Firstly, the amphipods do not affect the nematode assemblage sufficiently to alter the assemblage parameters, even at high densities. Secondly, the amphipods can affect the assemblage structure significantly, but due to experimental limitations, e.g. short experimental time (only negative effects detectable), fixed number of species due to absence of immigration, we were unable to demonstrate changes in assemblage pattern. Some studies have shown that nematodes can be quite resilient to pollution, with small or no changes in assemblage structure when perturbed (Alongi et al. 1983, Gee et al. 1985, Lambshead 1986, Warwick et al. 1988). This also applies to some studies on biological disturbance (Sherman et al. 1983, 'Olafsson et al. 1990), though in other cases significant differences have been found (Warwick et al. 1986, Warwick et al. 1990).

Among the temporary meiofauna, Macoma balthica spat were negatively affected by the presence of the amphipods, which is in accordance with Elmgren et al. (1986), who found the spat being crushed and probably eaten by the amphipods. Sundelin \& Elmgren. (1991) found that both $M$. balthica spat and ostracods were reduced in a long-term amphipod treatment.

The copepod assemblage consisted solely of 2 species, Microarthridion littorale and Pseudobradya $\mathrm{sp}$, both in the field and the microcosms. These 2 species seem to be the only representatives of the harpacticoid fauna found in an extensive area of the Baltic proper, below 20 to $30 \mathrm{~m}$, where they can occur in high densities [Sarvala 1971, Ankar \& Elmgren 1976 (Pseudobradya sp. was then identified as Halectinosoma abrau)].

Numbers of copepods increased on average with increasing numbers of amphipods. It seems that the bioturbating activity of the amphipods enhances the reproductive potential of the harpacticoids. How this is brought about remains speculative. Pseudobradya sp. showed a considerable increase in density in all treatments during the course of the experiment and its abundance was 2 times greater in the high amphipod density microcosms compared to other treatments, whereas Microarthridion littorale was only found in elevated numbers in the high amphipod density microcosms. Both of these species live in the top $\mathrm{cm}$ of the sediment. As the generation time of $M$. littorale is highly temperature dependent, of the order of $70 \mathrm{~d}$ at $15^{\circ} \mathrm{C}$ (Palmer \& Coull 1980), one would expect it to be considerably longer in the microcosms $\left(5^{\circ} \mathrm{C}\right)$ and not to be completed within the experimental period. However, post-embryonic development rates of harpacticoid copepods are strongly affected by quantity and quality of food resources (see Hicks \& Coull 1983 for review). It is possible that increased sediment rework- ing in the microcosms improved the available food resources, resulting in shorter generation times and therefore higher density. Alongi (1985) found, for example, that an epibenthic harpacticoid copepod became more abundant in cultures where the surface sediments were regularly disturbed, compared with no disturbance. The increasing number of dead amphipods associated with increasing numbers of amphipods may however have enhanced the food resources, thereby stimulating harpacticoid growth rate. Sundelin \& Elmgren (1991) also found enhanced levels of harpacticoids and turbellarians in high amphipod treatments and suggested that the presence of dead amphipods might stimulate scavenging turbellarians.

The nematode assemblage from the field station represents species that are typically found in brackish water environments (Heip et al. 1985). Species composition was similar to that found by Elmgren (1976) at a nearby station of similar bottom type and depth, the 6 most abundant species being the same. The dominance of Sabatieria pulchra in the microcosms and the different ranking of the most abundant species from the field can best be explained by the sampling technique. The bulk of the sediment was collected with a benthic dredge which inevitably results in considerable loss of surface material. S. pulchra is known to prefer anoxic or very low dissolved oxygen conditions which is often reflected in a deep vertical distribution (Bouwman 1983, Jensen 1984). Although we tried to compensate by enriching the microcosms with surface meiofauna, we were not entirely successful. However, exact duplication of the field species assemblage was not anticipated as modifications of environmental parameters inside the microcosms were bound to occur. Merely sieving the sediment can have drastic effects on the microbial biomass, growth rate and metabolic activity (Findlay et al. 1990) and may therefore affect the meiobenthos. Although some workers have been able to keep relatively rich meiofaunal assemblages in the laboratory (Hockin 1981, Warwick et al. 1988, Austen 1989) they usually do differ from observed field assemblages (McIntyre et al. 1970, Heip 1973, Gee et al. 1985), with a tendency for opportunistic species to become dominant.

While it is clear that biological disturbance may be important in structuring meiobenthic communities, it remains difficult to make general predictions concerning how soft-bottom communities will react to biotic perturbations. This is because biological disturbance is species specific, variable within and between habitats and difficult to scale according to intensity and frequency. Similarities between our results and the longer experiments of Sundelin \& Elmgren (1991) still suggest that the effects tend to be reproducible and therefore amenable to experimental investigation. 
Acknowledgement. We thank the staff of the Askö Laboratory field station for assistance and $B$. O. Jansson for making available facilities. Agnar Ingólfsson, Brian J. Bett. Cathy Hill and Colin G. Moore gave valuable comments on an earlier version of the manuscript. Thanks also to Richard Warwick and Melanie Austen for advice concerning the ANOSIM program. This study was supported by the Swedish Natural Science Research Council. The first author gratefully acknowledges the receipt of grants from the Nordic Council for Marine Biology, Nordic Council of Ministers, Hierta-Retzius stipendiefond and Letterstedtska Föreningen.

\section{LITERATURE CITED}

Alongi, D. M. (1985). Effect of physical disturbance on population dynamics and trophic interactions among microbes and meiofauna. J. mar Res. 43: 351-364

Alongi, D. M. Boesch, D. F., Diaz, R. J. (1983). Colonization of meiobenthos in oil-contaminated subtidal sands in the lower Chesapeake Bay. Mar Biol. 72: 325-335

Ankar, S., Elmgren, R. (1976). The benthic macro- and meiofauna of the Askö-Landsort area (northern Baltic proper). A stratified random sampling survey. Contrib. Askö Lab. Univ. Stockholm 11: 1-115

Austen, M. C. (1989). Factors affecting estuarine meiobenthic assemblage structure: a multifactorial microcosm experiment. J. exp. mar Biol. Ecol. 130: 167-187

Blomqvist, S., Abrahamsson, B. (1985). An improved Kajaktype gravity core sampler for sediments. Schweiz. Z. Hydrol. 47: 81-84

Bousfield, E. L. (1989). Revised morphological relationships within the amphipod genera Pontoporeia and Gammaracanthus and the 'glacial relict' significance of their postglacial distributions. Can. J. Fish. Aquat. Sci. 46: $1714-1725$

Bouwman, L. A. (1983). A survey of nematodes from the Ems estuary, Part II: Species assemblages and associations. Zool. Jb. Abt. Syst. Ökol. Geogr. Tiere 110: 345-376

Clarke, K. R. (1990). Comparisons of dominance curves. J. exp. mar. Biol. Ecol. 138: 143-157

Connell, J. H. (1978). Diversity in tropical rain forests and coral reefs. Science 199: 1301-1310

Creed, E. L., Coull, B. C. (1984). Sand dollar, Mellita quinquiesperfortata (Leske), and sea pansy, Renilla reniformis (Cuvier) effects on meiofaunal abundance. J. exp mar. Biol. Ecol. 84: 224-234

Dayton, P. K. (1971). Competition disturbance and community organization. The provision and subsequent utilization of space in a rocky intertidal community. Ecol. Monogr. 41: 351-389

Elmgren, R. (1976). Baltic benthos communities and the role of the meiofauna. Contrib. Askö Lab. Univ. Stockholm 14: $1-31$

Elmgren, R., Ankar, S., Marteleur, B., Ejdung, G. (1986). Adult interference with postlarvae in soft sediments: the Pontoporeia-Macoma example. Ecology 67. 827-836

Findlay, R. H., Trexler, M B., Guckert, J. B., White, D. C. (1990). Laboratory study of disturbance in marine sediments: response of a microbial community. Mar Ecol. Prog. Ser. 62: 121-133

Fitzhugh, G. R., Fleeger, J. W. (1985). Goby (Pisces: Gobildae) interactions with meiofauna and small macrofauna. Bull. mar Sci. 36: 436-444

Gee, J. M., Warwick, R. M., Davey, J. T., George, C. L. (1985). Field experiments on the role of epibenthic predators in determining prey densities in an estuarine mudflat. Estuar. coast. Shelf. Sci. 21: 429-488

Heip, C. (1973). Partitioning of a brackish water habitat by copepod species. Hydrobiologia 41. 189-198

Heip, C., Vincx, M., Vranken, G. (1985). The ecology of marine nematodes. Oceanogr. mar. Biol. Ann. Rev. 23: 399-489

Hicks, G. F. R. (1984). Spatio-temporal dynamics of a meiobenthic copepod and the impact of predation-disturbance. J. exp. mar. Biol. Ecol. 81: 47-72

Hicks, G. F. R., Coull, B. C. (1983). The ecology of marine meiobenthic harpacticoid copepods. Oceanogr. mar. Biol. Ann. Rev. 21. 67-175

Hill, M. O. (1979). DECORANA - a FORTRAN program for detrended correspondence analysis and reciprocal averaging. Cornell University, Ithaca, New York

Hill, C., Elmgren, R. (1987). Vertical distribution in the sediment in the co-occurring benthic amphipods Pontoporeia affinis and $P$. femorata. Oikos 49: 221-229

Hockin, D. C. (1981). Maintenance of a diverse harpacticoid copepod community in microcosm culture. Mar Biol. 65: 209-214

Huston. M. (1979). A general hypothesis of species diversity. Am. Nat. 113: 81-110

Jensen, P. (1984). Ecology of benthic and epiphytic nematodes in brackish waters. Hydrobiologia 108: 201-217

Lambshead, P. J. D. (1986). Sub-catastrophic sewage and industrial waste contamination as revealed by marine nematode faunal analysis. Mar. Ecol. Prog. Ser. 29: $247-260$

Lambshead, P. J. D., Platt, H. M., Shaw, K. M. (1983). The detection of differences among assemblages of marine benthic species based on an assessment of dominance and diversity. J. nat. Hist. 17: 859-874

Lopez, G., Elmgren, R. (1989). Feeding depths and organic absorption for the deposit-feeding benthic amphipods Pontoporeia affinis and P. femorata. Limnol. Oceanogr. 34 : 982-991

McIntyre, A. D., Munro, A. L. S., Steele, J. H. (1970). Energy flow in a sand ecosystem. In: Steele, J. H. (ed.) Marine food chains. Oliver \& Boyd, Edingburgh, p. 19-31

Moore, C. G. (1983). A BASIC program for the investigation of species diversity. Wat. Pollut. Control 82: 102-106

-Olafsson, E. Moore, C. G. (1990). Control of meiobenthic abundance by macroepifauna in a subtidal muddy habitat. Mar Ecol. Prog. Ser. 65: 241-249

-Olafsson, E., Moore, C. G., Bett, B. J. (1990). The impact of Melinna palmata Grube, a tube-building polychaete, on meiofaunal community structure in a soft-bottom subtidal habitat. Estuar. coast. Shelf. Sci. 31. 883-893

Paine, R. T (1966). Food web complexity and species diversity. Am. Nat. 100: 65-75

Palmer, M. A. (1988). Epibenthic predators and marine meiofauna: separating predation, disturbance, and hydrodynamic effects. Ecology 69: 1251-1259

Palmer, M. A., Coull, B. C. $(1980)$. The predication of development rate and the effect of temperature for the meiobenthic copepod, Microarthridion littorale (Poppe) J. exp. mar Biol. Ecol. 48: 73-83

Platt, H. M., Warwick, R. M. (1983). Free-living marine nematodes. Part I. British Enoplids. In: Kermach, D. M., Barnes, R. S. K. (eds.) Synopses of the British Fauna (New Series), 38 Cambridge University Press, Cambridge. p. $1-307$

Reidenauer, J. A.. Thistle, D. (1981). Response of a soft-bottom harpacticoid community to stingray (Dasyatis sabina) disturbance. Mar. Biol. 65: 261-267

Reise, K. (1979). Moderate predation on melofauna by the 
macrobenthos of the Wadden Sea. Helgoländer wiss. Meeresunters. 32: 453-465

Reise, K. Ax, P. (1979). A meiofaunal 'thiobios' limited to the anaerobic sulfide system of marine sand does not exist. Mar Biol. 54: 225-237

Robbins, J. A. (1982). Stratigraphic and dynamic effects of sediment reworking by Great Lakes zoobenthos. Hydrobiologia 92: 611-622

Sarvala, J. (1971). Rannikkovesiemme pohjaelaimistosta Luonnon Tutkija 75: 113-125

Sherman, K. M., Reidenauer, J. A., Thistle, D., Meeter, D. (1983) Role of natural disturbance in an assemblage of marine freeliving nematodes. Mar. Ecol. Prog. Ser. 11: 23-30

Sundelin, B., Elmgren, R. (1991). Meiofauna of an experimental soft bottom ecosystem - effects of macrofauna and cadmium exposure. Mar. Ecol. Prog. Ser. 70: 245-255

This article was presented by T. Fenchel, Helsingor, Denmark
Thistle, D. (1980). The response of a harpacticoid copepod community to a small-scale natural disturbance. J. mar. Res. 38: 381-395

Warwick, R. M., Carr, M. R., Clarke, K. R., Gee, J. M., Green, R. H. (1988). A mesocosm experiment on the effects of hydrocarbon and copper pollution on a sublittoral softsediment meiobenthic community. Mar Ecol. Prog. Ser. 46: $181-191$

Warwick, R. M., Clarke, K. R., Gee, J. M. (1990). The effect of disturbance by soldier crabs Mictyris platycheles $\mathrm{H}$. Milne Edwards on meiobenthic community structure. J. exp. mar. Biol. Ecol. 135: 19-33

Warwick, R. M., Gee, J. M., Berge, J. A., Ambrose, W. (1986). Effects of the feeding activity of the polychaete Streblosoma bairdi (Malmgren) on meiofaunal abundance and community structure. Sarsia 71: 11-16

Manuscript first received: October 30, 1990 Revised version accepted: May 3, 1991 